Original research article

\title{
Utilization of ADL performance tests to predict expected functional status in patients after stroke
}

\author{
Yvona Angerova ${ }^{1}$ *, Pavel Marsalek ${ }^{2}$, Anna Kratochvilova ${ }^{3}$, Irina Chmelova ${ }^{4,5}$, Tereza Gueye ${ }^{1}$, \\ Jan Briza ${ }^{6}$, Vladimir Rogalewicz ${ }^{1}$ \\ ${ }^{1}$ Charles University, First faculty of Medicine and General University Hospital, Department of Rehabilitation Medicine, Prague, Czech Republic \\ ${ }^{2}$ Masaryk Hospital in Ústí nad Labem, Krajská zdravotní, a.s., Rehabilitation Department, Ústí nad Labem, Czech Republic \\ ${ }^{3}$ Czech Technical University in Prague, Faculty of Biomedical Engineering, Department of Biomedical Technology, Kladno, Czech Republic \\ ${ }^{4}$ University Hospital Ostrava, Clinic of Rehabilitation and Physical Medicine, Ostrava, Czech Republic \\ ${ }^{5}$ University of Ostrava, Faculty of Medicine, Department of Rehabilitation, Czech Republic \\ ${ }^{6}$ General University Hospital, Prague, Czech Republic
}

\begin{abstract}
The main objective of this paper is the study of patient self-sufficiency functional tests in the early rehabilitation stage of stroke, and their further development in relation to the initial disability severity. Attention is paid to the identification of links between the first weeks of early rehabilitation therapy and the patients' state one year after their discharge from the early rehabilitation ward.

There were 87 patients in early rehabilitation wards in three different parts of the Czech Republic. One year after their discharge, 29 of them were tested again. The FIM (Functional Independence Measure) values from the follow-up check statistically significantly correlate with the severity of patients' functional disability at the time of admission one year ago (at the significance level of 0.05), more severe patients improved more than less severe ones. The same applies if we look at the effect of the number of days between the first onset of stroke and the admission to the early rehabilitation ward (at the significance level of 0.05 ). The sooner the patients were admitted, the bigger the improvement they could achieve.

Monitoring of changes in the functional state and the self-sufficiency progress in stroke patients is crucial for rehabilitation indication and the tracking of its outcomes. In the Czech Republic, unfortunately, we still tend to look for unified criteria for disability evaluation, and many patients must pass through the rehabilitation system without clear guidance.
\end{abstract}

Keywords: BI (Barthel Index); FIM (Functional Independence Measures); Neurorehabilitation; Patient outcome assessment; Stroke

\section{Introduction}

Stroke is a very serious, life-threatening illness that continues to carry a high mortality rate and is one of the most common causes of severe acquired disability in adults. According to the International Classification of Functioning, Disability and Health (ICF), disability is defined as an impairment of functionality on the level of an individual's body or on the level of society, which arises when the patient's condition is confronted with barriers in the environment (Švestková et al., 2017).

The most frequent sequela of a stroke is an impairment of the motor system resulting in a significant deterioration of patients' self-sufficiency and limitations to their participation in everyday life (Angerová et al., 2012; Katan and Luft, 2018). A patient's disability becomes even more serious as motor complications are paired with communication problems and/or cognitive impairments. The main objective of stroke treatment in the acute phase is to save the patient's life and minimise sequelae. There has been a saying used in acute stroke treatment in recent years: "Time is brain" (Zeiler, 2019), which accurately describes the crucial role of quick diagnosis and therapy. For a long time, stroke treatment focused exclusively on the acute phase of the illness. Although rehabilitation was recognised as an important part of the overall therapeutic process, a precise setting and detailed description of specific steps, or a "gold standard of therapy", has been more of a challenge.

In terms of epidemiology, stroke is the second most frequent cause of death worldwide and a significant cause of disability (Katan and Luft, 2018). Stroke incidence increases with the increasing average age of the global population. In emerging and developing countries, the number of younger people suffering from strokes is increasing as well. Stroke incidence and mortality vary in different countries, geographical regions and ethnic groups (Katan and Luft, 2018).

\footnotetext{
* Corresponding author: Yvona Angerova, Charles University, First faculty of Medicine and General University Hospital, Department of Rehabilitation Medicine, Albertov 7, 12808 Prague 2, Czech Republic; e-mail: angerova.yvona@vfn.cz http://doi.org/10.32725/kont.2021.xxx
} 
Over the past 30 years, improvements in prevention, acute treatment and neuro-rehabilitation have brought about a decrease in the number of stroke cases and in the severity of sequelae in developed countries, but worldwide, the ictus incidence has increased by $25 \%$ in the $25-65$ age group (Krishnamurthi et al., 2015). In the Czech Republic, a total of 33,826 persons were hospitalised with a stroke diagnosis, and 5,917 died in 2017.

Although stroke incidence has been declining in the Czech Republic (it dropped by $14.5 \%$ over the past decade, while mortality decreased by $28.5 \%$ ), it is still nearly twice that of some Western European countries (Bruthans, 2019). However, the hospital mortality is comparable with Western Europe and indicates high-quality acute care (Bruthans, 2019).

A variety of neuro-rehabilitation strategies are used to eliminate or minimise stroke sequelae. Neuro-rehabilitation is a multidisciplinary rehabilitation approach to patients with neurological diagnoses. It should be administered by an inter-professional (formerly interdisciplinary) team, since several systems may be affected at the same time. The team should consist of rehabilitation and physical medicine specialists who work in close partnership with other specialists. Other crucial team members include physiotherapists and occupational therapists, nurses, neuropsychologists and speech therapists. Nutritionists, prosthetics specialists, music therapists, dance therapists, biomedical engineers and other specialists have been increasingly involved in such teams as well.

A wide variety of evaluation tools have been developed to objectively assess self-sufficiency (Chen et al., 2013). A simple test is the Barthel Index (BI) (Mahoney and Barthel, 1965), a scoring questionnaire on activities of daily living. The test has been repeatedly criticised for not including very important cognitive aspects and the criticism eventually led to an introduction of the Extended Barthel Index (EBI), which does include these cognitive items (ÚZIS, 2018).

Despite the above mentioned extension of the test, the most widely used and highly regarded test of self-sufficiency is the FIM (Functional Independence Measures) test (Granger et al., 2010; Winstein et al., 2016). The test was developed in the USA in the Uniform Data Systems (UDS) environment. Data are centralised and users must attend regular training (Stiborová, 2017).

The aim of this study is to determine whether self-sufficiency tests are suitable for use in Czech conditions, whether these tests have a predictive value that could help with early stage patient selection to identify patients that could most benefit from intensive rehabilitation, and whether the tests can be used to (at least partially) predict the final functional state of the patient.

When discussing the choice of functional tests for her work on the prediction of undesirable events in stroke patients, Kurokawa et al. (2018) explained that she went systematically through 3,260 papers that indicated that FIM carried out at patient admission has a good validation for the prediction of future states throughout the rehabilitation process.

Chumney et al. (2010) found that the initial FIM score was the strongest predictor of the final functional state and it was the cognitive part of FIM that contributed most to this result.

\section{Materials and methods}

In 2016-2018, the Department of Rehabilitation Medicine of the First Faculty of Medicine of the Charles University and the General University Hospital (VFN), together with the Reha- bilitation Clinic of the University Hospital in Ostrava (FNO) and the Rehabilitation Department of the Masaryk Hospital in Ústí nad Labem (MNUL), participated in a project, supported by the General Health Insurance Company (VZP), aimed at an economic assessment of early rehabilitation of stroke patients (Angerová et al., 2020). The project studied economic indicators as well as clinical and rehabilitation aspects of stroke patient treatment. After the project ended, patients' progress was further monitored, although without more support from VZP. The main objective of this paper is the study of patient self-sufficiency functional tests in the early rehabilitation stage and their further development in relation to the initial disability severity. Special attention is paid to identifying links between the first weeks of early rehabilitation therapy and the patients' state one year after their discharge from the early rehabilitation ward.

Only patients with a potential for monitoring of all required data were included in the study sample. The initial basic input criterion was a stroke diagnosis not more than 70 days before the admission to the rehabilitation ward. The type of stroke (ischemic, embolic-ischemic or haemorrhagic) did not play a role. We also disregarded how the stroke occurred, and whether it was a primary stroke diagnosis or a complication of another medical condition such as an operation or catheterisation. The collected data included basic demographic data, medical information, length of hospitalisation, number of days between the stroke onset and hospitalisation in a rehabilitation ward, location and size of the lesion and further parameters.

The therapeutic evaluation focused primarily on the patients' overall functional state. We used the FIM test, when we assessed motor and cognitive aspects separately, and the Barthel Index. In this paper, the following abbreviations are used: BI - Barthel Index, EBI - Extended Barthel Index, FIM Functional Independence Measure, FIM M - the motor part of FIM, and FIM C - the cognitive part of FIM. The maximum possible score of each test is shown in Table 1.

\section{Table 1. Maximum possible scores in individual tests}

\begin{tabular}{lc} 
Test & Maximum possible score \\
\hline BI & 100 \\
RBI & 90 \\
ZBI + RBI & 190 \\
FIM M & 91 \\
FIM K & 35 \\
FIM & 126 \\
\hline
\end{tabular}

The tests were repeated at regular intervals of 14 days and were executed by occupational therapists who received identical training prior to the launch of the project in order to achieve the best possible conformity.

The project was designed as pragmatic, with each hospital following its own standard therapeutic procedures. Of course, these procedures had to meet the rules of the cerebrovascular programme (Bulletins of the Ministry of Healthcare of the Czech Republic 2/2010, 8/2010, 10/2012 and 11/2015), while the healthcare providers also had to arrange for technical equipment and staffing required by the Bulletins. All departments and clinics participating in the project had an inter-professional rehabilitation team consisting of specialists in the areas listed above. The therapy used in individual patients conformed to generally applicable principles of neuro-rehabilitation. 
Patient data collection continued without any grant support over a period of one year after the end of hospitalisation. Patients or their family members were contacted by phone. It was conscientiously followed whether the patients stayed at home or in a medical or social facility. The patients were invited to continue in this project and were offered a follow-up check at the rehabilitation departments in Prague, Ústí nad Labem or Ostrava.

Out of the 87 patients monitored during the acute stage early rehabilitation, only 29 showed up for the follow-up check. We were unable to contact many patients from Ostrava and Ústí nad Labem or any of their family members, and their current state is, therefore, unknown. Where we were able to get in touch with the patient or the family, we were often informed that the patient lived in a social care facility and we were provided with no more details about the patient's health condition. As for patients from the General Hospital in Prague, we failed to get in touch with five of them and another five had been admitted to long-term treatment facilities and were in such a severe condition that their transport for examination was impossible. Three patients in home care lived outside of Prague, their condition did not allow for independent travelling and the family did not agree to transport by ambulance. Two patients lived in retirement homes and were not willing to travel for examination. One patient lived entirely independently at home,but declined to participate in any further testing. Thus, it was possible to collect FIM scores and clinical data from the follow-up examinations one year after discharge for 29 patients. Clinical data obtained from the acute and oneyear follow-up stages were subjected to a statistical analysis using MS Excel and R software in order to assess the potential for predicting patient state one year after the discharge from the hospital. In addition to regular descriptive statistical methods, we also tested hypotheses related to the objection of the study. The FIM values from the follow-up check statistically significantly correlated with the severity of patients' functional disability at the time of admission one year ago; patients in a more severe state at the time of admission had a greater chance of improvement. Low FIM values at admission allow for a considerable improvement, and that's why the improvement after one year correlates with low FIM values at the time of admission as well as with FIM values at the time of discharge from the hospital.

\section{Results}

In the acute treatment phase, there were 87 patients in the sample, ranging from 31 to 95 years of age with the average age of 70.48 and median of 71 years. The sample included 49 men and 38 women. See Table 2 for details of the patient age distribution. The length of hospitalisation ranged from 4 to 59 days. The average length of the hospitalisation was 22.16 and the median 20 days. Details of the hospitalisation length are also shown in Table 2.

Table 2. Age distribution and number of days between stroke onset and the transfer to early rehabilitation ward

\begin{tabular}{|c|c|c|c|c|c|}
\hline \multirow[t]{2}{*}{ Age distribution } & \multirow[b]{2}{*}{$n$} & \multirow[b]{2}{*}{$\%$} & \multicolumn{3}{|c|}{$\begin{array}{l}\text { Number of days between stroke onset and the transfer to early } \\
\text { rehabilitation ward }\end{array}$} \\
\hline & & & & $n$ & $\%$ \\
\hline $0-39$ & 1 & 1.1 & $<7$ & 10 & 11.5 \\
\hline $40-49$ & 4 & 4.6 & $7-13$ & 40 & 46.0 \\
\hline $50-59$ & 14 & 16.1 & $14-20$ & 16 & 18.4 \\
\hline $60-69$ & 21 & 24.1 & $21-27$ & 6 & 6.9 \\
\hline $70-79$ & 23 & 26.4 & $28-34$ & 10 & 11.5 \\
\hline $80-89$ & 20 & 23.0 & $35-60$ & 3 & 3.4 \\
\hline $90+$ & 4 & 4.6 & $>60$ & 2 & 2.3 \\
\hline
\end{tabular}

The average time between the stroke onset and the patient's admission to an early rehabilitation facility was 16.2 days and the median was 11 days. The majority of patients were admitted between the 5th and 13th day after the stroke onset. In terms of stroke aetiology, there were 57 patients with ischemic stroke, 21 with embolic stroke, seven with haemorrhaging stroke, and two patients without a clearly identifiable cause. In most cases, post-stroke treatment was conservative. Intravenous thrombolysis (IVT) was conducted in 26 cases, intravascular intervention in nine cases, and two patients received surgery. The clinical findings of most patients included hemiparesis, with the same number of right-sided and left-sided (41). Five patients had other clinical symptoms, mostly brain stem disorders; typically balance impairment.

At the end of hospitalisation, 45 patients were released home, three of which required the intensive assistance of a relative and two of another person. Seventeen patients were transferred to other rehabilitation facilities, usually specialised rehabilitation centres or spa sanatoria. Eight patients were transferred to long-term care establishments due to a stagnation or worsening of their state, and four patients were transferred to social care facilities. Later, seven of them returned to acute care departments due to complications. Six patients were transferred to other unspecified locations. See Chart 1 for a detailed breakdown of where the patients were transferred after their discharge from each participating hospital.

In most patients, their functional state, assessed using BI or FIM, improved before the day when they were discharged from the early rehabilitation facility. Only one patient experienced a significant deterioration of his state due to complications at the end of hospitalisation. The state of three patients remained unchanged compared to the time of admission, but all three of them spent no more than five days in the rehabilitation ward - and thus received very little care.

The total average initial FIM was 78.2 as compared with the average final score of 90.9. The authors of this paper will present a comparison of the outcomes achieved in individual hospitals in another paper. 
The rate of functional state improvement during hospitalisation was calculated as the difference between the scores at the beginning and the end of rehabilitation in relation to the maximum possible values. As indicated in Chart 2, the difference is $12.3 \%$ in the case of FIM M, $4.3 \%$ in the case of FIM C, and $10.0 \%$ in the overall FIM. In the case of the Barthel Index, the improvement rate is $15.9 \%$ in the basic version, $5.9 \%$ for cognitive aspects, and the highest, $21.8 \%$, in aggregation of the two.

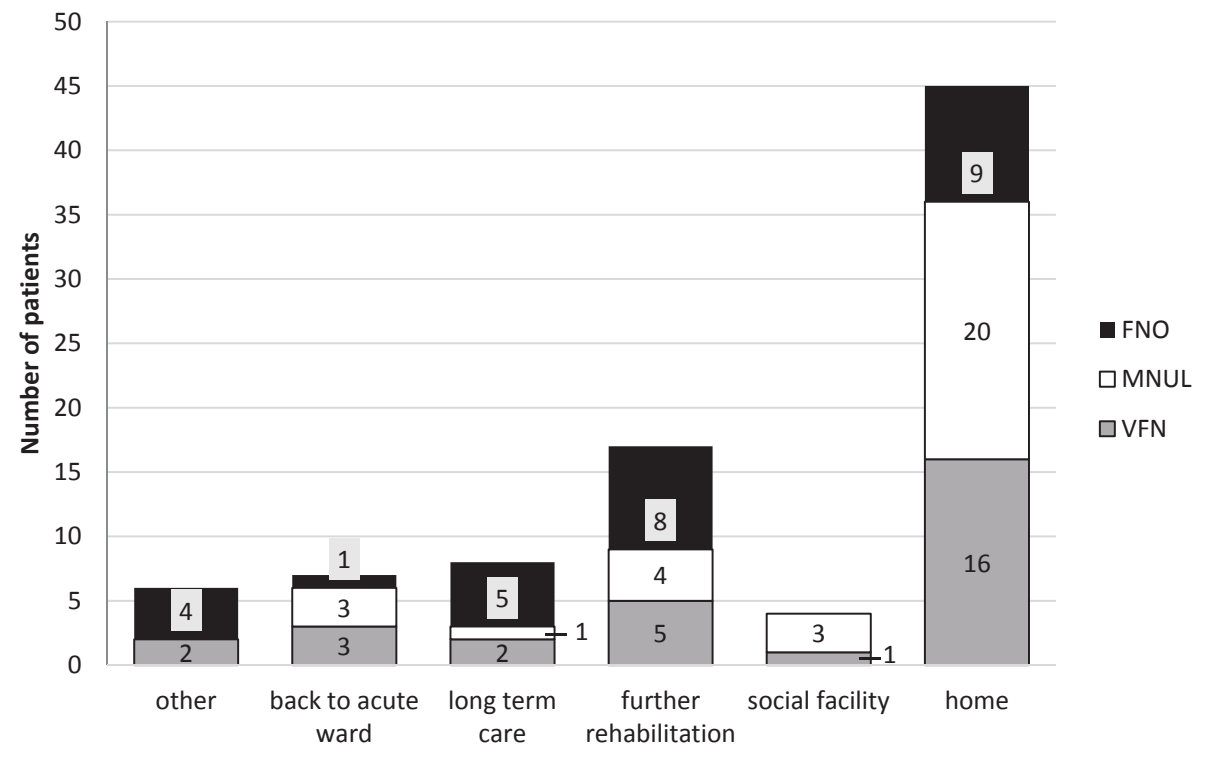

Chart 1. Patient discharge

Due to reasons stated above, we examined only 29 patients (33.3\% of the original sample) one year after the discharge from hospitals. Thirteen patients were originally treated in the General University Hospital in Prague, nine in the Masaryk Hospital in Ústí nad Labem and seven in the University Hospital Ostrava.

Table 3 shows the average values and medians of the FIM test as well as its motor and cognitive parts (FIM M, FIM C) at the time of discharge from the hospital and one year later. The FIM values from the follow-up check statistically significantly correlate (at the significance level of 0.05 ) with the severity of patients' functional disability at the time of admission one year ago, when patients in a more severe state at the time of admission had a greater chance of improvement. The earlier after the stroke onset a patient was admitted to the early rehabilitation ward, the greater his/her chance of improvement within a one-year period (again at the significance level of 0.05). Low FIM values at admission allow for a considerable improvement, and that's why the improvement after one year correlates with low FIM values at the time of admission as well as with FIM values at the time of discharge from the hospital, both at the significance level of 0.001 . A similar correlation

Table 3. FIM scores at the discharge from early rehabilitation and after one year

\begin{tabular}{llcc} 
& & Discharge & One year after discharge \\
\hline \multirow{2}{*}{ FIM } & average & 99.45 & 110.93 \\
& median & 114.00 & 116.00 \\
\multirow{2}{*}{ FIM M } & average & 71.17 & 81.24 \\
& median & 82.00 & 83.00 \\
\multirow{2}{*}{ FIM C } & average & 28.28 & 29.69 \\
& median & 31.00 & 32.00 \\
\hline
\end{tabular}

was proved in relation to the difference in FIM (final - initial) at the significance level of 0.05 .

Chart 3 shows the relationship between the length of hospitalisation and patients' improvement in FIM scores a year after discharge from the hospital. It clearly indicates a score divergence from the linear trend with growing length of hospitalisation. At first sight, however, there is a visible dispersion of values away from the regression line, also confirmed by statistical methods. The value of the Pearson correlation coefficient of 0.109 indicates a very weak correlation between the length of hospitalisation and changes in FIM. Chart 4 shows a divergence of points representing patients' improvements in FIM away from the linear trend with increasing patient age. However, according to the regression line, patient age does not have a decisive effect on a patient's progress measured by FIM one year after discharge from the hospital.

\section{Discussion}

Despite significant improvements in the acute care of stroke patients thanks to the establishment of stroke units, many stroke patients suffer from life-long consequences; however, their severity can be decreased through rehabilitation (Branco et al., 2019; Kwakkel et al., 2017; Zeiler, 2019). The process of rehabilitation begins during the acute phase in intensive care units, and as soon as the patients are stabilised, they are transferred to early rehabilitation wards that create a part of the stroke units (Bernhardt et al., 2015; Langhorne et al., 2017).

The functional state of patients was assessed using FIM and $\mathrm{BI}$ tests selected on the basis of our long-term experience as well as available literature (Branco et al., 2019; Chumney et al., 2010; Hsueh et al., 2002; Saito et al., 2018). An important goal of the study was to determine whether these tests, taken at the time of admission to the early rehabilitation wards, have 


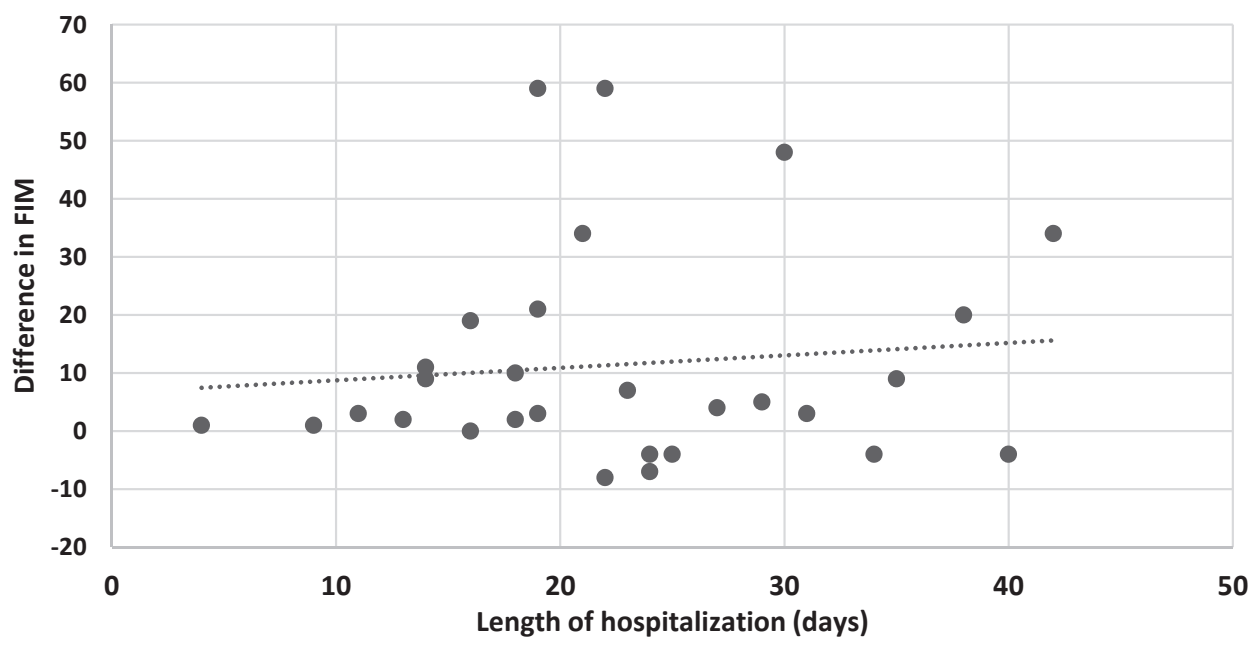

Chart 3. Relationship between the length of hospitalization and patient's improvement

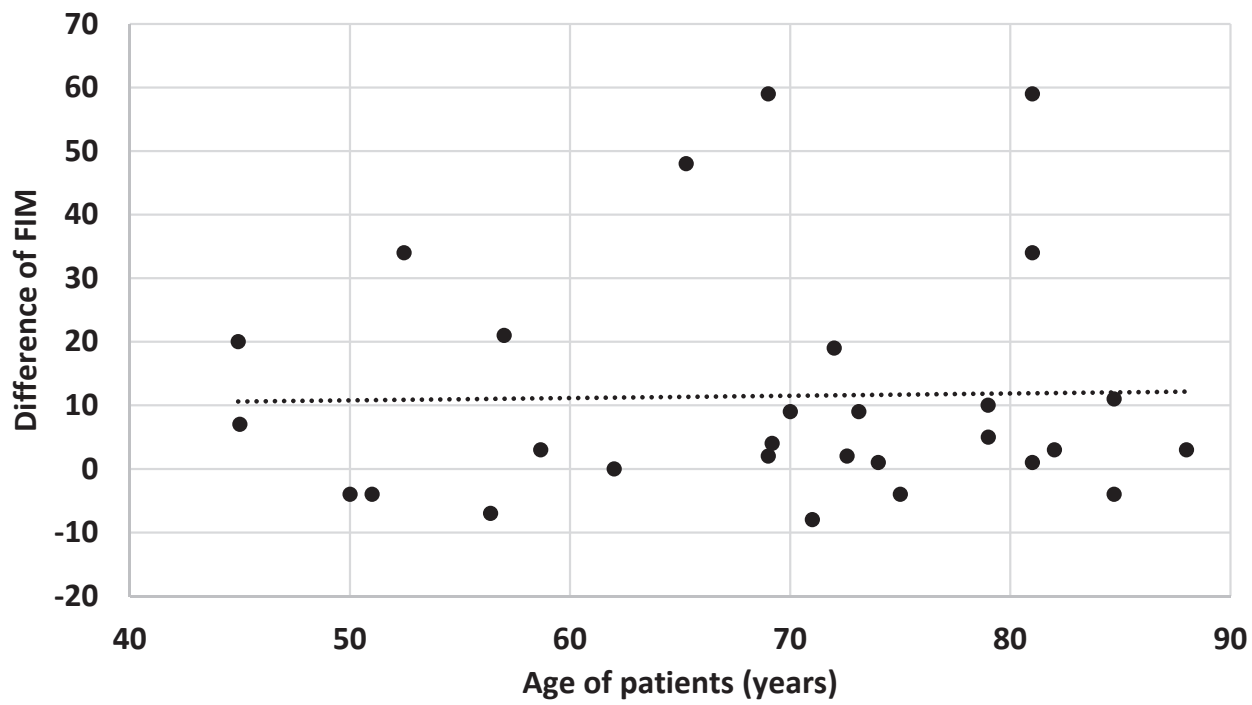

Chart 4. Relationship between difference in FIM scores at discharge and a year after and age of patients

any predictive value that could be potentially used as an indicator for the transfer to early rehabilitation wards and for setting an optimal personalized rehabilitation process.

Another important question was to what extent are BI and FIM interchangeable. This question was discussed in our previous article (Angerova et al., 2020). The tests, if properly conducted, proved a relatively good correlation in the motor component. In the cognitive component, on the other hand, FIM $C$ showed much greater fluctuations in comparison with EBI. This deviation might be explained by the effect of FIM's more precise manual that allows for better identification of lower cognitive disabilities (Branco et al., 2019; Chumney et al., 2010).

The predictive value of FIM was proved only in a small group of 29 patients that showed up for the one-year follow-up check. In this smaller group, FIM values significantly correlated with the severity of the functional state at admission one year ago. It might seem paradoxical that the lower a score patients got in the test on admission, i.e. the higher the severity of their functional state, the greater the chance of lat- er improvement. The same applies if we take into account the effect of the number of days from the first occurrence of stroke symptoms to admission to the early rehabilitation ward. The sooner a patient was admitted, the bigger the improvements they could achieve. The improvement is more dynamic in the initial phase after the ictus, which means that patients who did not improve much in the acute stage had more space for improvement over the subsequent year and some of them actually utilized this potential.

Although there have been repeated reports of cognitive functions having an impact on the overall functional state of a patient (Branco et al., 2019), we found no statistically significant results in our sample in terms of the impact of daily improvement of FIM $C$ to improvements of FIM M, or in terms of the impact of the initial or final values of FIM $C$ to daily improvement of FIM M. We found no statistical relationship between a patient's final functional state and his/her age, type of stroke, or stroke location.

The cause of the low statistical significance of our results is probably a small homogeneity of patients both within the 
individual categories and between them. Studies of the predictive power of self-sufficiency tests have often focused on very narrowly defined groups of patients, frequently only on patients with ischemic strokes in a. cerebri media (Branco et al., 2019; Saito et al., 2018). Another reason for differences in sample composition and length of hospitalisation between the hospitals may lie in different routines in the setting of indication criteria and the possibility to transfer patients to specialized rehabilitation centres or long-term care facilities. The study was designed as a pragmatic one and although there were clear therapeutic criteria, rehabilitation might have been also affected by particular therapists, their experience, personal approach, etc.

In order to plan rehabilitation and set precise personal goals in each case, it could be crucial to have a tool in the acute phase that would help predict how far the patient can get on his or her journey to self-sufficiency. There have been many studies attempting to make use of this property of FIM (Chumney et al., 2010; Hsueh et al., 2002; Kurokawa et al., 2018; Strasser et al., 2008). A systematic literature review was published as early as 2010 with the objective of assessing the suitability of FIM for the prediction of the final functional state in stroke patients across various population groups. Out of the total of 18 studies, six were finally selected thanks to their adherence to high standards of the Physiotherapy Evidence Database (PEDro) (Chumney et al., 2010). Only one of these studies was randomised and blinded (Strasser et al., 2008). The same study was also the only one to achieve the $1 \mathrm{~b}$ rating, while all the other studies were rated $2 \mathrm{~b}$ or worse.

Hsueh et al. (2002) found that FIM at admission to a rehabilitation facility has the Cronbach alpha of 0.88 , and 0.91 at discharge. Tur's study states the correlation between FIM at admission to a rehabilitation ward and age (-0.28), and between FIM and the length of hospitalisation (-0.39) (Tur et al., 2003). Non-zero correlations were also found between FIM at discharge and age (-0.35) or length of hospitalisation $(-0.50)$. There were three studies focused on validity. Hsueh et al. (2002) described correlation $(r>0.92)$ and an interclass correlation between FIM M and BI at admission and at discharge, which indicates high simultaneous validity. Only two studies separated the motor part of FIM, which undermines the construction validity and reliability of research results generalisation necessary for FIM to be validated as a tool for the evaluation of the final functional state (Chumney et al., 2010).

It has been repeatedly argued that a "spontaneous neurobiological recovery" can occur after a stroke. Unfortunately, we know no biological, clinical or neurophysiological markers that would accurately determine the degree of such supposed spontaneous improvement (Boyd et al., 2017). The time factor (improvement over time) alone explains $80-90 \%$ of the observed improvement of functions and activities over the first ten weeks after a stroke (Kwakkel et al., 2006). On the other hand, improvement attributable to the therapy was able to explain about $5-15 \%$ of beneficial changes in the functional state of patients participating in an active program six months after a stroke as compared with controls (Verbeek et al., 2014). The term "spontaneous" might be misleading as it reflects the in- ternal predetermined response or better reaction of the brain to a sudden focused damage. The expression that might better explain the processes at hand could be "a reactive neurobiological recovery", which is not the same as neuroplasticity (Winters et al., 2018). According to Bernhardt et al. (2016), neuroplasticity refers to various time periods during the first months after the ictus, reflecting processes of both the positive, but also the negative regulation supported by growth as well as inhibition factors (Murphy and Corbett, 2009).

In the light of these findings, the crucial area to investigate in order to support current neurorehabilitation after stroke is the plasticity related to motor learning and its ability to also affect processes that support the reactive neurobiological recovery. It is highly probable that, in the acute phase, patients with similar brain damage also have similar chances of improvement. This, however, appears to be just the starting point that must be completed with the individual time-dependent capacity for the reactive neurobiological recovery that may vary from patient to patient (Prabhakaran et al., 2008).

\section{Conclusions}

Monitoring of changes in the functional state and the self-sufficiency progress in stroke patients is crucial for rehabilitation indication and the tracking of its outcomes. In the Czech Republic, unfortunately, we still tend to look for unified criteria for disability evaluation, and many patients must pass through the rehabilitation system without clear guidance. While some patients might (sometimes entirely unintentionally) misuse the numerous rehabilitation options, others are denied even the most basic inter-professional rehabilitation. In this current project we tried to show that the established self-sufficiency tests that should be largely applied in the Czech Republic, even if used in a unified way, do not offer a clear predictive value, and that there are still many challenges ahead of us in terms of developing a systemic inter-professional rehabilitation suitable for particular stages of stroke treatment.

In conclusion, we must stress that the greatest challenge for research of the functional state development in stroke patients is an identification of key mechanisms supporting neurobiological recovery and their biomarkers. We need to develop innovative interventions that could boost these key mechanisms. The crucial task is to identify therapies that can turn patients with a poor response to treatment to well-responding patients in order to improve their recovery and foster their return to daily activities with minimal functional disability.

\section{Funding}

The research leading to this paper was supported by the grant No. 410004194 provided by the General Health Insurance Company of the Czech Republic from their Secondary Prevention Fund.

\section{Conflicts of interests}

The authors have no conflict of interests to declare. 


\section{Využití testů soběstačnosti $k$ predikci výsledného funkčního stavu pacientů po cévních mozkových příhodách}

\section{Souhrn}

Hlavním cílem př́ispěvku je sledování testů soběstačnosti v časné fázi po cévní mozkové př́hodě a vývoje jejich výsledků ve vztahu $\mathrm{k}$ tíži počátečního postižení pacientů. Pozornost je věnována hledání vztahu mezi rehabilitační léčbou a stavem pacientů rok po propuštění z oddělení včasné rehabilitace.

Ve sledovaném souboru bylo 87 pacientů z akutních lůžkových rehabilitačních oddělení na třech různých místech České republiky. Jeden rok po propuštění bylo znovu testováno 29 z nich. Hodnoty testu soběstačnosti FIM (Functional Independence Measures) z kontrolního hodnocení statisticky významně (na hladině významnosti 0,05 ) korelovaly s tíží disability při přijetí na popisovaná rehabilitační lůžka. Pacienti s těžším postižením se zlepšili více než pacienti s postižením lehčím. Ke stejnému výsledku dospějeme při sledování vlivu počtu dnů, které uplynuly mezi vznikem iktu a přijetím na rehabilitační lůžka. Čím dříve byli pacienti přijati, tím většího zlepšení mohli dosáhnout (na hladině významnosti 0,05 ).

Sledování vývoje funkčního stavu a zlepšování soběstačnosti je zcela zásadní pro indikaci rehabilitace a mapování jejích výsledků. V České republice bohužel stále ještě hledáme jednotná kritéria hodnocení disability a mnoho pacientů kvůli tomu prochází celým systémem rehabilitace bez jasného vedení.

Klíčová slova: BI (Barthel Index); cévní mozková příhoda; FIM (Functional Independence Measures); neurorehabilitace; závěrečné hodnocení pacientů

\section{References}

1. Angerova Y, Hralova M, Gueye T, Švestková O, Lippertova-Grünerova M (2012). Influence of enriched environment and erythropoietin on cognitive function of rats after hypobaric hypoxia. Brain Inj 26(4-5): 472-473.

2. Angerova Y, Marsalek P, Chmelova I, Gueye T, Uherek S, Briza J, et al. (2020). Cost and cost-effectiveness of early inpatient rehabilitation after stroke varies with initial disability: the Czech Republic perspective. Int J Rehabil Res 43(4): 376-382. DOI: 10.1097/MRR.0000000000000440.

3. Bernhardt J, Borschmann K, Boyd L, Thomas Carmichael S, Corbett D, Cramer SC, et al. (2016). Moving rehabilitation research forward: Developing consensus statements for rehabilitation and recovery research. Int J Stroke 11(4): 454-458. DOI: 10.1177/1747493016643851.

4. Bernhardt J, English C, Johnson L, Cumming TB (2015). Early mobilization after stroke: early adoption but limited evidence. Stroke 46(4): 1141-1146. DOI: 10.1161/ STROKEAHA.114.007434.

5. Boyd LA, Hayward KS, Ward NS, Stinear CM, Rosso C, Fisher RJ, et al. (2017). Biomarkers of Stroke Recovery: Consensus-Based Core Recommendations from the Stroke Recovery and Rehabilitation Roundtable. Neurorehabil Neural Repair 31(10-11): 864-876. DOI: $10.1177 / 1545968317732680$.

6. Branco JP, Oliveira S, Sargento-Freitas J, Laíns J, Pinheiro J (2019). Assessing functional recovery in the first six months after acute ischemic stroke: a prospective, observational study. Eur J Phys Rehabil Med 55(1): 1-7. DOI: 10.23736/S19739087.18.05161-4.

7. Bruthans J (2019). Epidemiologie a prognóza cévních mozkových př́ihod v ĆR. CMP Journal 2(1): 5-8.

8. Chen H-F, Wu C-Y, Lin K-C, Chen C-L, Huang P-C, Hsieh C-J, Liu J-S (2013). Rasch validation of a combined measure of basic and extended daily life functioning after stroke. Neurorehabil Neural Repair 27(2): 125-132. DOI: $10.1177 / 1545968312457828$.

9. Chumney D, Nollinger K, Shesko K, Skop K, Spencer M, Newton RA (2010). Ability of Functional Independence Measure to accurately predict functional outcome of stroke-specific population: systematic review. J Rehabil Res Dev 47(1): 17-29. DOI: 10.1682/jrrd.2009.08.0140.
10. Granger CV, Markello SJ, Graham JE, Deutsch A, Reistetter TA, Ottenbacher KJ (2010). The uniform data system for medical rehabilitation: report of patients with traumatic brain injury discharged from rehabilitation programs in 2000-2007. Am J Phys Med Rehabil 89(4): 265-278. DOI: 10.1097/ PHM.0b013e3181d3eb20.

11. Hsueh I-P, Lin J-H, Jeng J-S, Hsieh C-L (2002). Comparison of the psychometric characteristics of the functional independence measure, 5 item Barthel index, and 10 item Barthel index in patients with stroke. J Neurol Neurosurg Psychiatry 73(2): 188-190. DOI: 10.1136/jnnp.73.2.188.

12. Katan M, Luft A (2018). Global Burden of Stroke. Semin Neurol 38(2): 208-211. DOI: 10.1055/s-0038-1649503.

13. Krishnamurthi RV, Moran AE, Feigin VL, Barker-Collo S, Norrving B, Mensah GA, et al. (2015). Stroke Prevalence, Mortality and Disability-Adjusted Life Years in Adults Aged 20-64 Years in 1990-2013: Data from the Global Burden of Disease 2013 Study. Neuroepidemiology 45(3): 190-202. DOI: $10.1159 / 000441098$.

14. Kurokawa N, Kai C, Hokotachi $Y$, Hasegawa M, Amagai T (2018). Determination of the cut-off point of the Functional Independence Measure as a predictor of adverse events in patients with acute stroke. J Int Med Res 46(10): 4235-4245. DOI: 10.1177/0300060518792155.

15. Kwakkel G, Kollen B, Twisk J (2006). Impact of time on improvement of outcome after stroke. Stroke 37(9): 2348 2353. DOI: 10.1161/01.STR.0000238594.91938.1e.

16. Kwakkel G, Lannin NA, Borschmann K, English C, Ali M, Churilov L, et al. (2017). Standardized measurement of sensorimotor recovery in stroke trials: Consensus-based core recommendations from the Stroke Recovery and Rehabilitation Roundtable. Int J Stroke 12(5): 451-461. DOI: 10.1177/1747493017711813.

17. Langhorne P, Wu O, Rodgers H, Ashburn A, Bernhardt J (2017). A Very Early Rehabilitation Trial after stroke (AVERT): a Phase III, multicentre, randomised controlled trial. Health Technol Assess 21(54): 1-120. DOI: 10.3310/hta21540.

18. Mahoney FI, Barthel DW (1965). Functional evaluation: The Barthel index. Md State Med J 14: 61-65.

19. Murphy TH, Corbett D (2009). Plasticity during stroke recovery: from synapse to behaviour. Nat Rev Neurosci 10(12): 861-872. DOI: $10.1038 / \mathrm{nrn} 2735$.

20. Prabhakaran S, Zarahn E, Riley C, Speizer A, Chong JY, Lazar RM, et al. (2008). Inter-individual variability in the 
capacity for motor recovery after ischemic stroke. Neurorehabil Neural Repair 22(1): 64-71. DOI: 10.1177/1545968307305302.

21. Saito J, Koyama T, Domen K (2018). Long-Term Outcomes of FIM Motor Items Predicted From Acute Stage NIHSS of Patients With Middle Cerebral Artery Infarct. Ann Rehabil Med 42(5): 670-681. DOI: 10.5535/arm.2018.42.5.670.

22. Stiborová A (2017). Funkční míra nezávislosti a míra hodnocení funkčního stavu FIM + FAM jako nástroj pro hodnocení funkčního stavu v neurorehabilitaci. Neurol praxi 18(5): 330-333. DOI: 10.36290/neu.2017.107.

23. Strasser DC, Falconer JA, Stevens AB, Uomoto JM, Herrin J, Bowen SE, et al. (2008). Team training and stroke rehabilitation outcomes: a cluster randomized trial. Arch Phys Med Rehabil 89(1): 10-15. DOI: 10.1016/j.apmr.2007.08.127.

24. Švestková O, Angerová Y, Druga R (2017). Rehabilitace motoriky člověka [Human motor activity Rehabilitation]. Grada Publishing.

25. Tur BS, Gursel YK, Yavuzer G, Kucukdeveci A, Arasil T (2003). Rehabilitation outcome of Turkish stroke patients: in a team approach setting. Int J Rehabil Res 26(4): 271-277. DOI: 10.1097/00004356-200312000-00004.
26. ÚZIS - Institute of Health Information and Statistics of the Czech Republic (2018). Barthelové test. [online] [cit. 2020-01-22]. Available from: https://www.uzis.cz/index. php?pg=registry-sber-dat--klasifikace--barthelove-test

27. Veerbeek JM, van Wegen E, van Peppen R, van der Wees PJ, Hendriks E, Rietberg M, Kwakkel G (2014). What is the evidence for physical therapy poststroke? A systematic review and meta-analysis. PLoS One 9(2): e87987. DOI: 10.1371/ journal.pone.0087987.

28. Winstein CJ, Stein J, Arena R, Bates B, Cherney LR, Cramer SC, et al. (2016). Guidelines for Adult Stroke Rehabilitation and Recovery: A Guideline for Healthcare Professionals from the American Heart Association / American Stroke Association. Stroke 47(6): e98-e169. DOI: 10.1161/ STR.0000000000000098.

29. Winters C, Kwakkel G, van Wegen EEH, Nijland RHM, Veerbeek JM, Meskers CGM (2018). Moving stroke rehabilitation forward: The need to change research. NeuroRehabilitation 43(1): 19-30. DOI: 10.3233/NRE-172393.

30. Zeiler SR (2019). Should We Care About Early Post-Stroke Rehabilitation? Not Yet, but Soon. Curr Neurol Neurosci Rep 19(3): 13. DOI: 10.1007/s11910-019-0927. 